Boise State University

ScholarWorks

4-1-2016

\title{
The Influence of the Online Availability of USGS Topographic Maps on Weeding Decisions in Academic Libraries
}

Cheri A. Folkner

Boise State University

Mary C. Aagard

Boise State University 


\title{
The Influence of the Online Availability of USGS Topographic Maps on Weeding Decisions in Academic Libraries
}

\author{
Cheri A. Folkner \\ Albertsons Library \\ Boise State University \\ Mary C. Aagard \\ Albertsons Library \\ Boise State University
}

\begin{abstract}
This study looked at the degree to which the online availability of U.S. Geological Survey historical topographic maps affects academic libraries' decisions to withdraw the print versions of those maps. Other factors in making the decisions, such as usage, user preferences, support of academic programs, user discovery, shelving location, and printing options, were also investigated. Results show that while in $40 \%$ of the cases the online USGS historical topographic maps influenced the decision to weed, the need for space was the overwhelming driver of print USGS topographic map collection weeding within the past ten years.
\end{abstract}

Keywords: topographic maps, weeding, online availability, academic libraries, space

\section{Introduction}

Topographic maps from the U.S. Geological Survey (USGS) have long been a mainstay of many U.S. academic library map collections. The Guide to U.S. Map Resources, 3rd ed., edited by Christopher J.J. Thiry (2006) indicates that of the more than 330 map collections in academic libraries, at least 269 comprise USGS maps to some extent. The USGS has produced topographic maps since it was authorized by Congress to begin the systematic topographic mapping of the United States in 1884 (Usery, Varanka, and Finn 2009). By 2006, when the U.S. Geological Survey ceased printing topographic maps (USGS 2015b, under “Older Topographic Maps”), libraries had been receiving USGS maps for 120 years (Pritchett 2015, 7). In 2011, the U.S. Geological Survey established the Historical Topographic Map Collection "to provide a digital repository of USGS 1:250,000 scale and larger maps printed between 1884, the inception of the topographic mapping program, and 2006” (USGS 2015a). With the advent of the online availability of these maps, some libraries saw an opportunity to begin weeding USGS topographic maps from their collections (Hans Raum, email to MAPS-L@listserv.uga.edu).

The authors undertook a survey to gather information from academic libraries about their USGS topographic map collections, the retention decisions regarding them, and whether the factor of the USGS making its historical topographic maps available online influenced libraries' decision to weed their paper archives of those maps. Through the data collected, the authors examined the influence of online availability in the context of other factors affecting collection and retention decisions, such as type of institution, need for space, patron use, cataloging availability, printer/plotter availability, and whether the topographic maps supported any specific academic program.

\section{Literature Review}

Regular weeding of library collections is a recommended practice for libraries, and the influx of digitized materials in library collections has led to libraries withdrawing some corresponding print materials. In his handbook on weeding, Slote (1997, 3-5) outlines several reasons to weed library collections: to save space, to increase usage, to increase reader satisfaction, to save staff time, and to make room for new technology. In considering why librarians have not weeded more aggressively "in view of the pressing space problem" $(1997,5)$ he summarizes the following factors that discourage weeding: the number of books in a library as an indicator of quality, time pressures, public displeasure 
This is an author-produced, peer-reviewed version of this article. The final, definitive version of this document can be found online at Collection Management, published by Routledge. Copyright restrictions may apply. doi: 10.1080/01462679.2016.1159162

with weeding, emotional and intellectual blocks against weeding, and conflicting collection criteria (1997, 5-6). Schonfeld and Housewright $(2009,2)$ found additional rationales for not weeding print materials in favor of online availability: "the need to fix scanning errors; insufficient reliability of the digital provider; inadequate preservation of the digitized versions; the presence of significant quantities of important non-textual material that may be poorly represented in digital form; and campus political considerations.”

Literature on weeding map collections is scarce and focuses on using a collection development policy to determine criteria for withdrawal. General articles of practice, weeding manuals, or books on collection development either do not mention maps at all (Slote 1997, Gregory 2011, Disher 2007) or mention them only in the context of atlases (Larson 2012, 40). Larsgaard $(1998,5)$ mentions that a collection's withdrawal policy is implied in its collection development policy, "shown by areas of greatest emphasis, cutoff dates for acquisition, and so forth." Articles on operationalizing the map collection development policy for withdrawal are either dated (Selmer 1979, Le 1983) or do not take the online availability of maps into account (Dawson 2015). At the 2014 annual meeting of the Western Association of Map Libraries, a sounding board discussion reflected on the reasons for libraries to retain their paper archives regardless of the online Historical Topographic Map Collection: "to ensure access during sequestrations and shutdowns; to guarantee preservation by storing in diverse places; and we sometimes have versions that their own archives lacks" (Rockwell 2014). The USGS acknowledges that no complete set of USGS historical maps exists, nor is there a catalog listing all of the maps produced by the USGS (Allord, Fishburn, and Walter 2014, 2).

Libraries have been grappling with decisions regarding the replacement of print materials with online access since the 1990s, particularly within the realm of journal literature. Ogburn (1996) editorialized about the possibility of replacing print with fulltext access, but Fennessy et al.'s (1997) informal survey showed not much print was being dropped due to online acquisitions. Fifteen years later, King $(2012,152)$ reported that academic members of the Association of Research Libraries (ARL) "have strongly embraced a move toward the provision of online information" in their reference collections.

Academic libraries provision of online access to journals without a print archive seems to have gained general acceptance by library users. The Ithaka S+R US Faculty Survey 2012 indicates that faculty accept the idea of libraries replacing current print journal subscriptions with online access, but are less enamored with the idea of discarding print in favor of online access (Housewright, Schonfeld, and Wulfson 2013, 26). This same survey showed that 70\% of faculty are using digital scholarly monographs in some manner (31).

Users' attitudes towards the acceptability of digital as a replacement for print maps is less clear cut. Faculty acceptance of online maps is not addressed by the Ithaka S+R US Faculty Survey 2012. In their study on the relative effectiveness of paper and electronic topographic maps to learn map-reading skills, Pedersen, Farrell, and McPhee $(2005,198)$ report that almost $80 \%$ of the students preferred using paper maps over electronic maps although there was no difference in map skill performance based on format used. Work by Hurst and Clough (2013) indicates that people with more geographic skill expertise prefer paper maps while non-experts prefer online maps. Their results also show that the task being undertaken influences the preference; paper maps are preferred "when planning and executing navigation on foot" while "there is a clear preference for mobile GPS devices when executing (rather than planning) short- and long-distance routes” (57). More recently Incoul, Ooms and De Maeyer (2015) studied whether the format of a map with the same content and scale influenced the attentive behavior of the user when that behavior is measured by registering the user's eye movement. The participants in their study indicated that the format of the map did not affect the efficient completion of the study tasks, even though content of the online map was interpreted more efficiently (354).

Users' acceptance of online access in lieu of print for some materials present libraries an opportunity to free up space by deaccessioning materials. Thomas and Shouse $(2012,96)$ point out "the changing natures of libraries from warehouses to service points puts pressure on libraries to give up stacks space for user space.” The need for space has contributed to the decision by some mid-size academic libraries to discard the National Union Catalog, Pre-1956 Imprints (NUC) (Abbott and Scherlen 2013). Abbott and Schelen point out the NUC occupies "almost 125 linear feet of oversized shelving” (120). Decreasing available space was also a reason cited for weeding government documents in Anderson's (2009, abstract) survey of thirty-three North Carolina depository libraries. 
This is an author-produced, peer-reviewed version of this article. The final, definitive version of this document can be found online at Collection Management, published by Routledge. Copyright restrictions may apply. doi: 10.1080/01462679.2016.1159162

Widespread deaccessioning of the same materials by many libraries raises the specter of libraries being unable to provide access to materials not held in their print and online collections. Schoenfeld and Housewright $(2009,4)$ discuss the overlap of collections by college and university libraries and how that overlap gave a sense of security regarding preservation. The Federal Depository Libraries Program (FDLP) is one of the "few coordinated efforts to manage collections at a system-wide level to accomplish community preservation goals” (Schonfeld and Housewright 2009, 5).

Part of the FDLP's coordinative efforts are specific guidelines for weeding depository materials. Qualification of material for weeding by selective depository libraries is through one of three ways: being superseded, being substituted, or having been held for five years (FDLP 2015). USGS maps, including topographic maps, have been distributed through the FDLP since 1984 (Larsgaard 1998, 105) and must meet the weeding criteria outlined by the FDLP. All printed topographic maps would meet the criterion of being held for five years because the USGS ceased printing maps in 2006, although permission to withdraw must be granted by the regional depository library (FDLP 2015).

In spite of these restrictions, as libraries try to reinvent their physical spaces to focus more on user collaborative work areas and to expand capacity to house new technologies, downsizing map collections may come under consideration because of their large footprint. U.S. map libraries typically use horizontal steel drawer cases and Larsgaard (1998, 218) recommends that a library not stack more than three cases with five drawers each in an open stack collection. Bahn (1961, fig. 1) calculates fifteen drawers will take up twelve square feet and weigh over 1,800 pounds when filled with maps, resulting in a floor load of 158 pounds per square foot. Using Bahn's data and assuming 400 topographic maps per drawer, the cabinet area required to house print versions of the 178,000 plus maps in the USGS Historical Topographic Map Collection (USGS 2015a) is 360 square feet. If space of four and a half feet is allowed for opening and accessing the maps, an additional 540 square feet would be needed. Actual square footage required may be more than these calculations. The map cases at the authors' institution each have a footprint of over fifteen square feet, $25 \%$ more than the 12 square feet that Bahn allows. In addition, filing 400 topographic maps per drawer can make map access difficult for patrons and often results in maps being damaged, so fewer maps per drawer is desirable. Unless a library has support reinforcement for its upper floors, the floor load requires map collections be on a ground floor (Bahn 1961, 4) -- always prime real estate in renovation projects.

\section{Methodology}

The objective of this study was to determine the influence that the online availability of USGS historical topographic maps had on academic libraries' decisions to withdraw print maps. In addition, the authors wanted to discover how academic libraries factored in usage, user preferences, academic programs, user discovery, shelving location, and printing options when making those decisions. Other factors investigated included Carnegie Classification of the parent institution, geographic location (including whether the institution was located in a state with high federal land ownership) and library federal depository status.

Academic libraries with USGS topographic map collections were identified using Guide to U.S. Map Resources (Thiry 2006). The resource provides a list of ninety academic libraries holding 100,000 maps or more, and this list was added to by reviewing the Library/Institution index for entries that appeared to be academic institutions. Each identified entry was reviewed to determine if the map collection held, or might hold USGS topographic maps. Some entries only indicated the collection had USGS maps, while others specifically stated the collection included USGS topographic maps. Two hundred and sixty-nine map collections remained in the study after those not holding any USGS maps were removed.

The contact information provided in the Guide to U.S. Map Resources (Thiry 2006) is almost a decade old, so a current contact was sought by searching the libraries' websites. Although this effort was both difficult and time consuming, the authors felt a survey would be more successful if the instrument were sent to a specific responsible person rather than a generic email account. Contact information from the Guide to U.S. Map Resources (Thiry 2006) was a good starting point even when it wasn't current, as it indicated a possible organizational structure that helped in the hunt. If a library's website had no person identified as being in charge of the map collection, contact information for those in charge of government documents or having geography or geosciences related liaison duties was used. As a last resort, 
This is an author-produced, peer-reviewed version of this article. The final, definitive version of this document can be found online at Collection Management, published by Routledge. Copyright restrictions may apply. doi: 10.1080/01462679.2016.1159162

a generic email account was used. The search of libraries’ websites found some map collections had closed or merged, and others were not actually part of an academic library. Two hundred and fifty-nine map collections in 244 academic institutions remained in the survey pool after completing the website reviews.

A survey tool was developed to characterize the USGS topographic map collections in academic libraries and to discover whether and why those collections had been weeded. The "Carnegie Classifications Data File" (Carnegie Foundation for the Advancement of Teaching 2012) provided information on the academic institution and Federal Land Ownership: Overview and Data (Gorte et al. 2012) provided information on a state's federal land ownership. Three published survey results on libraries' weeding of unique formats or materials were used as models for survey development: Abbott and Scherlen (2013) examined the deaccessioning of the NUC in mid-size academic libraries, King (2012) investigated weeding of reference collections in ARL academic libraries, and Keogh (2012) surveyed libraries regarding considerations when deciding to retain or discard microform collections. Building on these successful surveys and using Dillman's (2007) Mail and Internet Surveys: the Tailored Design Method as a guide, questions were developed to address

- holdings of USGS topographic maps and their geographic coverage,

- whether and how usage is measured,

- specific academic programs supported by the collection,

- collection storage location,

- cataloging of the collection,

- printer/plotter availability (participants in Hurst and Clough's $(2013,54)$ study commented on print capabilities improving online/digital map provision services) and

- collection weeding decisions including the reasons for those decisions,

Qualtrics software was used to create the survey instrument. The survey and survey process were submitted to and approved by the authors' institutional review board. The survey was distributed on May 19, 2015, and participants were given until June 19, 2015 to respond. Reminders were sent to those who had not completed the survey on June 4 and June 11. Responses were exported out of Qualtrics and correlated with Carnegie Classification institutional data.

\section{Results}

Surveys were sent to 259 panelists in 244 academic institutions; 113 panelists from 110 academic institutions completed the survey yielding a $43.6 \%$ response rate. One panelist reported USGS topographic maps had not been held within the past ten years, resulting in 112 responses from 109 academic institutions. Not every question was answered by every respondent so the number of responses per question varied.

\section{$\underline{\text { Institutional Data }}$}

Virtually all the respondents work for parent four-year academic institutions. The majority are from public, large fouryear institutions that are doctorate granting and having undergraduate majority enrollment. No geographic region dominates; all Carnegie Classification geographic regions were represented except US Service Schools and Outlying areas. A substantial minority of the institutions were located in states the Congressional Research Service defines as having concentrated federal land ownership - Alaska with 62\% federal land ownership and the 11 coterminous western states with $47 \%$ federal land ownership (Gorte et al. 2012, 1). (Table 1)

\section{Geographic Coverage and Access}

Seventy-five percent of the respondents have broad collections that include USGS topographic maps covering the United States or the United States, Puerto Rico and the Virgin Islands. The remainder are more narrowly focused on regional or state USGS topographic maps. In only $12 \%$ of the collections are patrons restricted from retrieving topographic maps themselves. It is most common that the maps are in open stacks and freely retrievable by patrons; $65 \%$ of the respondents indicated that is the case. Another $23 \%$ of the respondents house their collection in both open and restricted locations. 
This is an author-produced, peer-reviewed version of this article. The final, definitive version of this document can be found online at Collection Management, published by Routledge. Copyright restrictions may apply. doi: 10.1080/01462679.2016.1159162

Most respondents make their USGS topographic maps discoverable by including them in the online catalog. Over $80 \%$ have all or some of their USGS topographic maps in the online catalog. The level of cataloging is relatively evenly divided with 39\% cataloging the maps at the sheet level, 26\% cataloging them at the state level, and $27 \%$ cataloging them at either the sheet or state level. (Table 2)

\section{Usage and Users}

Just under $40 \%$ of the respondents measure usage of their USGS topographic maps and do so by counting maps left out after use, recording circulation statistics, or both. The vast majority of those that measured usage did so continuously, not just during a statistical snapshot or for a special project. Almost two-thirds of the respondents characterized the use of the collection as decreasing. Respondents were asked which patron group they believe most frequently uses their print USGS topographic map collection. No one patron group was overwhelming selected. Undergraduates were perceived to be the largest patron group with community patrons perceived to be the second most frequent users of the collections. (Table 3)

In addition to looking at patron groups, respondents were asked if the USGS topographic map collections supported any particular academic program or discipline at their institution. Eighty-one libraries (72\%) reported that the collection supported a particular program or discipline; of those responding in the affirmative, $100 \%$ of them supported at least one undergraduate program and $81 \%$ supported at least one graduate program. (Table 4 ) Twenty-one different undergraduate programs were mentioned as being supported by the USGS topographic map collections with Geology/Geoscience/Earth Science named by $75 \%$ and Geography named by $69 \%$. In fourteen libraries only one undergraduate program was specifically supported by the collection while in one library the collection supported fourteen undergraduate programs. The pattern for graduate programs was similar: nineteen different graduate programs were named with Geology/Geoscience/Earth Science and Geography being named, respectively, by 63\% and $62 \%$ of those whose collections supported a graduate program. Nineteen libraries reported supporting only one graduate program, and one library listed thirteen graduate programs supported by the collection. (Figure 1)

\section{$\underline{\text { Plotter/Printer Access and Purchase }}$}

Just over half of the respondents reported that patrons have access to a plotter/printer at their institution, and $60 \%$ of those indicated the plotter/printer was located in the library rather than another place on campus. Only two respondents said that the plotter/printer was purchased based on the online availability of the USGS historical topographic maps. (Table 5)

\section{Weeding of the Collection}

A slight majority of the respondents had weeded their print USGS print topographic maps within the last ten years. While $45 \%$ of this group had weeded within the past two years, $88 \%$ had weeded within the last five years. Those involved in the weeding decisions besides librarians/library staff were teaching/research faculty (9\%) and library administrative staff (5\%). Two-thirds of the weeding libraries weeded $25 \%$ or less of the collection. The need for space was by far (74\%) the most often cited reason for weeding the collection followed by low usage (41\%) and online availability (40\%). Thirty-three percent cited the need for space as the only reason for weeding. The other sole reasons cited were low usage (3\%) and "other" (14\%). Online availability was selected by $40 \%$ as a reason to weed, but it was not selected as the sole reason by any respondent. Other reasons to weed the collection named by the respondents were ongoing collection maintenance, collection merger/branch shutdown, condition issues, duplication, damaged cases had to be removed, and GIS data available.

Those who had weeded their collection were asked to describe the criteria used to make retention decisions. The criteria fell into eight categories. Forty-four percent removed at least some duplicates from their collection. Just under a third of the respondents based the decision on the edition of the maps and whether the map was within their geographic emphasis area. Many of those kept all editions within their geographic emphasis, while a few retained only the most recent edition. Twenty-eight percent reduced the overall geographic coverage of their collection. Twentytwo percent based the decision on the edition and whether the map was outside their geographic emphasis. Most of those kept only the most recent edition outside their geographic emphasis area, but one retained two editions, the oldest and the most recent. Other factors considered in retention decisions were physical condition, map scale, usage, and program support. 
This is an author-produced, peer-reviewed version of this article. The final, definitive version of this document can be found online at Collection Management, published by Routledge. Copyright restrictions may apply. doi: 10.1080/01462679.2016.1159162

The top reasons for not weeding the collection were patrons' desire to use print, staff time, and to guarantee preservation at $51 \%, 49 \%$, and $47 \%$ respectively. Eleven percent cited staff time as the sole reason for not weeding. The other reasons cited as the sole reason for not weeding were patrons' desire to use print (8\%), high usage (4\%) and "other" (8\%). Six respondents (13\%) who had not weeded their collections indicated not having a printer/plotter as a contributor to the decision, although only one indicated they would weed if a printer/plotter were available. Other reasons not to weed the collection named by the respondents were depository considerations, no compelling reason to weed, collection policy, printer/plotter expense, and unsure of usage. (Table 6)

Relationship Between the Decision to Weed and Other Variables

The decision to weed was compared with several variables using the chi-square test of independence to determine if there was any significant relationship between them. Responses of "I don't know" were removed from the data analysis. The number of expected counts for a valid chi-square test was not met for comparing Carnegie Basic Classification, perceived use, Carnegie geographic region, records in the online catalog, and shelving location so no comparison was made. No statistically significant relationship, $p=0.05$, was found when comparing the decision to weed with whether usage was measured, the library was located in a western state with large federal land ownership, whether a plotter/printer was available on campus, shelving location (remote or closed stacks vs. open stacks), and depository library status. Non-depository libraries were removed from the analysis when comparing depository status to the decision to weed.

There was a statistically significant relationship between the decision to weed and whether the print USGS topographic map collection supported any specific academic program $\left(X^{2}(1, N=100)=3.91, p<0.05\right)$. Of the seventy-six respondents who indicated the collection is supporting at least one specific program and knew if they had weeded or not, forty-six had weeded and thirty had not. The expected results would be forty-two that would have weeded and thirty-four that would not have weeded. Of the twenty-four that indicated the collection is not supporting any specific program, nine had weeded and fifteen had not. The expected counts would be thirteen would have weeded and eleven would not have weeded. This indicates that if the collection supports a specific program, there is a higher likelihood of weeding.

\section{Discussion}

The findings from this survey captured weeding decision-making processes for academic libraries with print USGS topographic map collections and whether weeding occurred due to online availability of USGS historical topographic maps. Over half of the respondents had weeded their print USGS collections within the last ten years, with $45 \%$ of them doing so within the last two years. For those who considered online availability when making the decision to weed, the timing is understandable because of the establishment of the online USGS Historical Topographic Map Collection in 2011.

While the results indicated the availability of the online USGS historical topographic maps influenced the decision for $40 \%$ of the those libraries that had weeded their print USGS topographic map collections, the online USGS historical topographic maps was not the sole reason for weeding of the print collection for any respondent. The need for space was the overwhelming reason for weeding the collection with $74 \%$ citing that as a contributor to the decision and 33\% citing it as the sole reason. As space needs are often the prime reason for weeding projects, this finding was unsurprising (Thomas and Shouse 2012, Abbott and Scherlen 2013, Anderson 2009). That online availability was not a contributor for more of the libraries and that having a printer/plotter available did not have a relationship to the decision was unexpected but may have been a result of $41 \%$ reporting the collection was weeded due to low usage and, therefore, online access and printing capabilities would not have been important. Only $38 \%$ of the respondents indicated their library measured usage of the print USGS topographic maps and there was no statistically significant association between those who measured usage and those who weeded $\left(X^{2}(1, N=101)=0.27, p<0.05\right)$.

The reported reasons for not weeding confirm those found in the literature; the top reasons reported were patrons desire to use print, staff time, and guarantee preservation at 51\%, $49 \%$, and $47 \%$ respectively. Patrons desire to use print is supported by the reports that students and people with more geographic skill expertise prefer paper maps (Pedersen, Farrell, and McPhee 2005, Hurst and Clough 2013). Time pressures are cited by Slote (1997) as a factor in libraries not weeding and preservation issues are discussed by Schonfeld and Housewright (2009) and in the 2014 annual meeting of the Western Association of Map Libraries sounding board discussion (Rockwell 2014). The 
This is an author-produced, peer-reviewed version of this article. The final, definitive version of this document can be found online at Collection Management, published by Routledge. Copyright restrictions may apply. doi: 10.1080/01462679.2016.1159162

importance of guaranteeing preservation and patrons desire to use print may be seen even in the criteria used by those libraries weeding their collections where the most prevalent criterion was duplication. Forty-four percent of those that weeded removed duplicates which resulted in the maps being preserved and the patrons still having access to the print version. With the high number of guaranteeing preservation responses, the authors hypothesized that regional depository libraries would be less likely to weed than selective depositories, but no statistically significant association was found $\left(\mathrm{X}^{2}(1, \mathrm{~N}=101)=0.31, p<0.05\right)$.

The statistically significant association of the print USGS topographic map collection that supports a specific academic program with a higher likelihood of weeding was counterintuitive. One possible reason for the relationship may be that those libraries where the collection supports a specific program may be tending to the collection better, making sure that it is focused on the needs of their users by regular weeding. A more likely reason may be that those libraries have priorities, such as the need for space, that outweigh the support of the program(s). It should be noted that there is not a statistically significant association if a significance level of $1 \%$ is selected. Further research is needed to determine if there is a causal relationship.

\section{Conclusion}

This survey of 259 academic map collections shows over half of the respondents have weeded their print USGS topographic map collections within the last ten years, with the overwhelming majority doing so in response to the need for space. The online availability of the USGS historical topographic maps influenced the decision to weed the print collection in a large number of cases but was not the decisive reason to weed. In fact, low usage of the collection was cited as a reason to weed just as frequently as online availability was. Less than half of the respondents reported measuring print USGS topographic map usage. Whether a library measured usage, was located in a western state with large federal land ownership, had a plotter/printer available on campus, shelved the collection in closed stacks, or its depository status did not have a statistically significant relationship to the decision to weed. The one factor that did have a statistically significant relationship to the decision to weed was whether the print USGS topographic map collection supported a specific academic program. That relationship was contradictory to expectation, showing collections that supported a specific program were more likely to be weeded. Further research is needed to determine if the relationship is causal.

\section{References}

Abbott, John P., and Allan G. Scherlen. 2013. "NUC, Quo Vadis? Have Mid-Size Academic Libraries Retained the National Union Catalog Pre-1956 Imprints?” Collection Management 38 (2): 119-142. doi:10.1080/01462679.2013.763740.

Allord, Gregory J., Kristin A. Fishburn, and Jennifer L. Walter. 2014. Standard for the U.S. Geological Survey Historical Topographic Map Collection. ver. 2. U. S. Geological Survey Techniques and Methods 11-B3. Reston, VA: U. S. Geological Survey. http://pubs.usgs.gov/tm/11b03/.

Anderson, Matt. 2009. “Trends in Libraries' Retention and Weeding of Government Documents.” MS thesis, University of North Carolina at Chapel Hill. http://dc.lib.unc.edu/cdm/ref/collection/s_papers/id/1715.

Bahn, Catherine I. 1961. "Map Libraries: Space and Equipment.” Bulletin - SLA Geography and Map Division. 46:3-17.

Carnegie Foundation for the Advancement of Teaching. 2012. "Carnegie Classifications Data File.” (cc2010_classification_data_file_07.14.2014.xls; accessed April 10, 2015). http://carnegieclassifications.iu.edu/resources/

Dawson, Emily-Jane. 2015. "Weeding the Map Collection: Observations and Advice.” WAML Information Bulletin 46 (2). http://www.waml.org/ib/waml-information-bulletin/46-2/weeding-the-map-collection-observationsand-advice/.

Dillman, Don A. 2007. Mail and Internet Surveys: the Tailored Design Method. 2nd ed., 2007 update ed. Hoboken: John Wiley \& Sons.

Disher, Wayne. 2007. Crash Course in Collection Development. Westport, CT: Libraries Unlimited.

FDLP. 2015. “Weeding a Depository Collection.” US Government Publishing Office. Last updated January 9, 2015. http://www.fdlp.gov/requirements-guidance/guidance/30-weeding-a-depository-collection.

Fennessy, Eamon T., Anne Jennings, Kathy Miraglia, and Linda Albright. 1997. “Are You Still Keeping Paper Titles Even If You Have Electronic Access?” Against the Grain 9 (3): 69. 
This is an author-produced, peer-reviewed version of this article. The final, definitive version of this document can be found online at Collection Management, published by Routledge. Copyright restrictions may apply. doi: 10.1080/01462679.2016.1159162

Gorte, Ross W., Carol Hardy Vincent, Laura A. Hanson, and Marc R. Rosenblum. 2012. Federal Land Ownership: Overview and Data. Washington, D.C.: Congressional Research Service. https://fas.org/sgp/crs/misc/R42346.pdf.

Gregory, Vicki L. 2011. Collection Development and Management for 21st Century Library Collections: an Introduction. New York: Neal-Schuman Publishers.

Housewright, Ross, Roger C. Schonfeld, and Kate Wulfson. 2013. Ithaka S+ R US Faculty Survey 2012. New York: ITHAKA. http://sr.ithaka.org/?p=22502.

Hurst, Paul, and Paul Clough. 2013. “Will We Be Lost Without Paper Maps in the Digital Age?” Journal of Information Science 39 (1): 48-60. doi:10.1177/0165551512470043.

Incoul, Annelies, Kristien Ooms, and Philippe De Maeyer. 2015. "Comparing Paper and Digital Topographic Maps Using Eye Tracking.” In Modern Trends in Cartography: Selected Papers of CARTOCON 2014, edited by Jan Brus, Alena Vondrakova, and Vit Vozenilek, 339-356. Switzerland: Springer.

Keogh, Patricia. 2012. "Decisions in Resource Management: the Case of Microforms.” Library Collections, Acquisitions, \& Technical Services 36 (1/2): 8-17. doi:10.1016/j.lcats.2011.04.003.

King, Nathaniel. 2012. "Nice vs. Necessary: Reference Collections in ARL Member Libraries.” Reference Librarian 53 (2): 138-155. doi:10.1080/02763877.2011.607415.

Larsgaard, Mary Lynette. 1998. Map Librarianship: an Introduction. 3rd ed. Englewood, CO: Libraries Unlimited.

Larson, Jeanette. 2012. CREW: a Weeding Manual for Modern Libraries. Austin, TX: Texas State Library and Archives Commission.

https://www.tsl.texas.gov/sites/default/files/public/tslac/ld/ld/pubs/crew/crewmethod12.pdf.

Le, Loan. 1983. “The Map Collection in a Small Academic Library: Scarborough College.” ACML Bulletin 46:1215.

Ogburn, Joyce L. 1996. “Is Fulltext Half Full or Half Empty?” Against the Grain 8 (6): 70.

Pedersen, Paula, Pat Farrell, and Eric McPhee. 2005. "Paper versus Pixel: Effectiveness of Paper versus Electronic Maps to Teach Map Reading Skills in an Introductory Physical Geography Course.” Journal of Geography 104 (5):195-202. doi:10.1080/00221340508978984

Pritchett, Hallie. 2015. "Mapping the Nation and Beyond: Maps from the Federal Government.” Paper presented at the 2015 DLC Meeting and FDL Conference, Washington, D.C. http://www.fdlp.gov/filerepository/outreach/events/depository-library-council-dlc-meetings/2015-meeting-proceedings-1/2015-dlcmeeting-and-fdl-conference/2648-mapping-the-nation-and-beyond-maps-from-the-federal-government/file.

Rockwell, Ken. 2014. "WAML 2014 Meeting Summary.” WAML Information Bulletin 46 (1). http://www.waml.org/ib/waml-information-bulletin/46-1/waml-2014-meeting-summary/.

Schonfeld, Roger C. and Ross Housewright. 2009. What to Withdraw? Print Collections Management in the Wake of Digitization. [New York?]: Ithaka S + R. http://www.sr.ithaka.org/sites/default/files/reports/What_to_Withdraw_Print_Collections_Management_in_ the_Wake_of_Digitization.pdf.

Selmer, Marsha L. 1979. “A Policy for Withdrawal from the Map Collection.” Bulletin - SLA Geography and Map Division 116:2-6.

Slote, Stanley J. 1997. Weeding Library Collections: Library Weeding Methods. 4th ed. Englewood, CO: Libraries Unlimited.

Thiry, Christopher J.J., ed. 2006. Guide to U.S. Map Resources. 3rd ed. Lanham, MD: Scarecrow Press.

Thomas, William Joseph and Daniel L. Shouse. 2012. "Rules of Thumb for Deselecting, Relocating, and Retaining Bound Journals.” Collection Building 31 (3): 92-97. doi:10.1108/01604951211243470.

Usery, E. Lynn, Dalia Varanka, and Michael P. Finn. 2009. "125 Years of Topographic Mapping: USGS History, Part 1: 1884-1980.” ArcNews Online, Fall 2009. http://www.esri.com/news/arcnews/fall09articles/125years.html.

USGS. 2015a. “The National Map: Historical Topographic Map Collection.” USGS. Last modified July 28, 2015. http://nationalmap.gov/historical/.

USGS. 2015b. “US Topo Quadrangles—Maps for America.” USGS. Last modified October 1, 2015. http://nationalmap.gov/ustopo/. 
This is an author-produced, peer-reviewed version of this article. The final, definitive version of this document can be found online at Collection Management, published by Routledge. Copyright restrictions may apply. doi: 10.1080/01462679.2016.1159162

Figure 1. Academic programs supported by the USGS print topographic collection

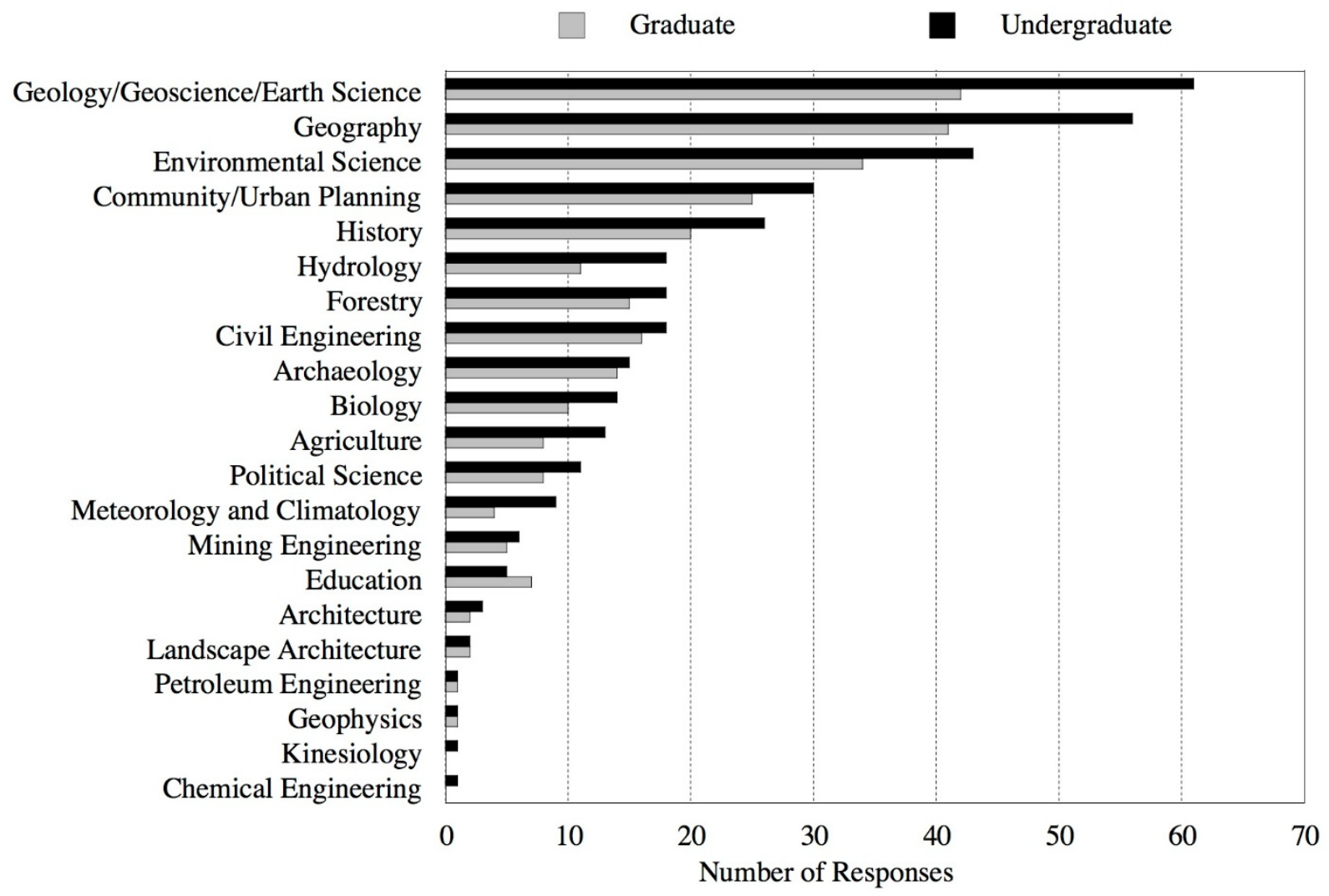


This is an author-produced, peer-reviewed version of this article. The final, definitive version of this document can be found online at Collection Management, published by Routledge. Copyright restrictions may apply. doi: 10.1080/01462679.2016.1159162

Table 1. Characteristics of institutions of respondents

\begin{tabular}{|c|c|c|}
\hline Characteristic & $\mathbf{n}$ & $\%$ \\
\hline \multicolumn{3}{|l|}{ Carnegie level of institution } \\
\hline Four or more years & 109 & 99 \\
\hline At least 2 but less than 4 years & 1 & 1 \\
\hline \multicolumn{3}{|l|}{ Carnegie control of institution } \\
\hline Public & 86 & 78 \\
\hline Private not-for-profit & 24 & 22 \\
\hline \multicolumn{3}{|l|}{ Carnegie size } \\
\hline Large four-year & 77 & 70 \\
\hline Medium four-year & 19 & 17 \\
\hline Small four-year & 12 & 11 \\
\hline Other & 2 & 2 \\
\hline \multicolumn{3}{|l|}{ Carnegie enrollment profile } \\
\hline High undergraduate & 55 & 50 \\
\hline Majority undergraduate & 24 & 22 \\
\hline Very high undergraduate & 19 & 17 \\
\hline Majority graduate/professional & 7 & 6 \\
\hline Exclusively undergraduate four-year & 4 & 4 \\
\hline Exclusively undergraduate two-year & 1 & 1 \\
\hline \multicolumn{3}{|l|}{ Carnegie basic classification } \\
\hline Research Universities(very high research activity) & 48 & 44 \\
\hline Research Universities(high research activity) & 22 & 20 \\
\hline Master's Colleges and Universities(larger programs) & 20 & 18 \\
\hline Baccalaureate Colleges--Arts \& Sciences & 5 & 5 \\
\hline Master's Colleges and Universities(smaller programs) & 5 & 5 \\
\hline Doctoral/Research Universities & 4 & 4 \\
\hline Baccalaureate Colleges--Diverse Fields & 2 & 2 \\
\hline Master's Colleges and Universities(medium programs) & 2 & 2 \\
\hline Associate's--Public Rural-serving Large & 1 & 1 \\
\hline Special Focus Institutions--Schools of engineering & 1 & 1 \\
\hline \multicolumn{3}{|l|}{ Carnegie geographic region } \\
\hline Great Lakes IL IN MI OH WI & 21 & 19 \\
\hline Far West AK CA HI NV OR WA & 20 & 18 \\
\hline Southeast AL AR FL GA KY LA MS NC SC TN VA WV & 20 & 18 \\
\hline Southwest AZ NM OK TX & 16 & 15 \\
\hline Plains IA KS MN MO NE ND SD & 13 & 12 \\
\hline Rocky Mountains CO ID MT UT WY & 8 & 7 \\
\hline Mid East DE DC MD NJ NY PA & 6 & 5 \\
\hline New England CT ME MA NH RI VT & 6 & 5 \\
\hline \multicolumn{3}{|l|}{ Concentrated federal land ownership state } \\
\hline West(AK AZ CA CO ID MT NV NM OR UT WA WY) & 32 & 29 \\
\hline Rest of the United States & 78 & 71 \\
\hline \multicolumn{3}{|l|}{ Depository library* } \\
\hline Selective & 82 & 73 \\
\hline Regional & 29 & 26 \\
\hline Not a depository library & 2 & 2 \\
\hline \multicolumn{3}{|l|}{ *Includes all 113 libraries, not just parent institutions } \\
\hline $\begin{array}{l}\text { Note: Some percentages do not add up to } 100 \% \text { due to rounding } \\
\text { error }\end{array}$ & & \\
\hline
\end{tabular}


This is an author-produced, peer-reviewed version of this article. The final, definitive version of this document can be found online at Collection Management, published by Routledge. Copyright restrictions may apply. doi: 10.1080/01462679.2016.1159162

Table 2. Print USGS topographic map collection coverage and access

\begin{tabular}{|c|c|c|}
\hline & $\mathbf{n}$ & $\%$ \\
\hline \multicolumn{3}{|l|}{ Broadest geographic coverage in the last 10 years } \\
\hline United States, Puerto Rico, and US Virgin Islands & 60 & 54 \\
\hline United States & 24 & 21 \\
\hline Regional & 22 & 20 \\
\hline State & 6 & 5 \\
\hline \multicolumn{3}{|l|}{ Location } \\
\hline Open stacks freely retrievable by patrons & 72 & 65 \\
\hline Closed stacks on-site & 12 & 11 \\
\hline Remote storage & 1 & 1 \\
\hline Some combination of the above & 26 & 23 \\
\hline \multicolumn{3}{|l|}{ In online catalog } \\
\hline Yes, some of them & 64 & 57 \\
\hline Yes, all of them & 29 & 26 \\
\hline No & 19 & 17 \\
\hline \multicolumn{3}{|l|}{ Level of online cataloging } \\
\hline Multiple bibliographic records -- for each sheet & 36 & 39 \\
\hline $\begin{array}{l}\text { Multiple bibliographic records -- some at the state level and } \\
\text { some at sheet level }\end{array}$ & 25 & 27 \\
\hline Multiple bibliographic records -- one for each state & 24 & 26 \\
\hline Don't know & 5 & 5 \\
\hline One bibliographic record for the entire collection & 2 & 2 \\
\hline Other & 1 & 1 \\
\hline
\end{tabular}


This is an author-produced, peer-reviewed version of this article. The final, definitive version of this document can be found online at Collection Management, published by Routledge. Copyright restrictions may apply. doi: 10.1080/01462679.2016.1159162

Table 3. Print USGS topographic map collection usage and users

\begin{tabular}{lrr}
\hline & $\mathbf{n}$ & $\mathbf{\%}$ \\
\hline Library measures usage & & \\
Yes & 42 & 38 \\
No & 65 & 58 \\
Don't know & 5 & 4 \\
How usage is measured where it is measured & & \\
Maps left out are counted/Circulation statistics are recorded & 25 & 60 \\
Maps left out are counted & 8 & 19 \\
Circulation statistics are recorded & 8 & 19 \\
Other & 1 & 2 \\
Frequency of use measurement where it is measured & & \\
Continuously & 38 & 90 \\
During specific internal project & 2 & 5 \\
During a statistical snapshot period for external reporting & 1 & 2 \\
purposes & & \\
Other & 1 & 2 \\
Perceived usage rate characterization & & \\
Decreasing & 26 & 63 \\
Remaining constant & 13 & 32 \\
Increasing & 2 & 5 \\
Patron group believed to most frequently use & & \\
Undergraduate students & 30 & 27 \\
Community patrons & 23 & 21 \\
Don't know & 24 & 21 \\
Graduate students & 18 & 16 \\
Faculty or staff & 17 & 15
\end{tabular}

Note: Some percentages do not add up to $100 \%$ due to rounding error

Table 4. Print USGS topographic map collection support of academic programs/disciplines

\begin{tabular}{lrr}
\hline & $\mathbf{n}$ & $\mathbf{\%}$ \\
\hline Collection supports particular programs or disciplines & & \\
Yes & 81 & 72 \\
No & 24 & 21 \\
Don't know & 7 & 6 \\
Note: Percentages do not add up to 100\% due to rounding error & & \\
Level of program supported (n=81) & & \\
$\quad$ Supports at least one undergraduate program & 81 & 100 \\
$\quad$ Supports at least one graduate program & 66 & 81 \\
\hline
\end{tabular}


This is an author-produced, peer-reviewed version of this article. The final, definitive version of this document can be found online at Collection Management, published by Routledge. Copyright restrictions may apply. doi: 10.1080/01462679.2016.1159162

Table 5. Printer/plotter access and purchase

\begin{tabular}{lrr}
\hline & $\mathbf{n}$ & $\mathbf{\%}$ \\
\hline Patrons have access at institution & & \\
Yes & 63 & 56 \\
No & 46 & 41 \\
Don't know & 3 & 3 \\
Location at institution & 38 & 60 \\
$\quad$ Library & 25 & 40 \\
$\quad$ Other campus location & & \\
Library purchased based on the online availability of USGS & & \\
historical topographic maps & 59 & 97 \\
$\quad$ No & 2 & 3 \\
Yes & & \\
\hline
\end{tabular}


This is an author-produced, peer-reviewed version of this article. The final, definitive version of this document can be found online at Collection Management, published by Routledge. Copyright restrictions may apply. doi: 10.1080/01462679.2016.1159162

Table 6. Weeding of print USGS topographic map collection in the last ten years

\begin{tabular}{|c|c|c|}
\hline & $\mathbf{n}$ & $\%$ \\
\hline \multicolumn{3}{|l|}{ Have weeded } \\
\hline Yes & 58 & 52 \\
\hline No & 45 & 40 \\
\hline Don’t know & 9 & 8 \\
\hline \multicolumn{3}{|l|}{ When did weeding last occur } \\
\hline Within the last year & 19 & 33 \\
\hline Within the last two years & 7 & 12 \\
\hline Within the last five years & 25 & 43 \\
\hline Don’t remember, don’t know or didn’t answer & 7 & 12 \\
\hline \multicolumn{3}{|c|}{ Who was involved in the weeding decisions (57 respondents selected all that applied) } \\
\hline Librarians/Library staff & 57 & 100 \\
\hline Teaching and research faculty & 5 & 9 \\
\hline Library administrative staff & 3 & 5 \\
\hline Other & 0 & 0 \\
\hline \multicolumn{3}{|l|}{ Quantity withdrawn } \\
\hline 0 to $25 \%$ & 39 & 67 \\
\hline $26 \%$ to $50 \%$ & 7 & 12 \\
\hline $51 \%$ to $75 \%$ & 6 & 10 \\
\hline $76 \%$ to $100 \%$ & 6 & 10 \\
\hline \multicolumn{3}{|l|}{ Reasons for weeding (58 respondents selected all that applied) } \\
\hline Need for space & 43 & 74 \\
\hline Low usage of the collection & 24 & 41 \\
\hline Online availability of USGS historical topographic maps & 23 & 40 \\
\hline Collection not in online catalog & 4 & 7 \\
\hline Discontinuation of academic program & 0 & 0 \\
\hline Other & 14 & 24 \\
\hline \multicolumn{3}{|l|}{ Weeding criteria (categorized responses from 54 respondents) } \\
\hline Removed duplicates & 24 & 44 \\
\hline Editions for emphasized geographic area & 17 & 31 \\
\hline Reduced geographic coverage & 15 & 28 \\
\hline Reduced editions for non- emphasized geographic area & 12 & 22 \\
\hline Physical condition & 4 & 7 \\
\hline Scale & 4 & 7 \\
\hline Usage & 2 & 4 \\
\hline Program support & 1 & 2 \\
\hline \multicolumn{3}{|l|}{ Reasons for not weeding (45 respondents selected all that applied) } \\
\hline Patrons' desire to use print & 23 & 51 \\
\hline Staff time & 22 & 49 \\
\hline Guarantee preservation & 21 & 47 \\
\hline Have versions that aren't online & 13 & 29 \\
\hline Ensure access during government shutdowns & 12 & 27 \\
\hline Other & 12 & 27 \\
\hline Public relations concerns & 8 & 18 \\
\hline No plotter/printer available for patron use & 6 & 13 \\
\hline High cost of removal & 5 & 11 \\
\hline High usage & 4 & 9 \\
\hline \multicolumn{3}{|c|}{$\begin{array}{l}\text { If lack of access to plotter/printer contributed to the decision not to weed, would you } \\
\text { weed if patrons had access to one }\end{array}$} \\
\hline Yes & 1 & 17 \\
\hline No & 5 & 83 \\
\hline
\end{tabular}


